\title{
SUSTAINABLE DEVELOPMENT DIRECTIONS OF RURAL TOURISM OF TIMOK REGION
}

\author{
Biljana Ilic ${ }^{1}$, Gordana Djukic ${ }^{2}$, Mladenka Balaban ${ }^{3}$ \\ *Corresponding authorE-mail: mladenka.balaban@bba.edu.rs
}

\begin{abstract}
A R T I C LE I N F O
A B S T R A C T

Original Article

Received: 27 January 2020

Accepted: 04 March 2020

doi:10.5937/ekoPolj2001157I

UDC 502.131.1:338.48-

44(497.11 Timočka Krajina)

In Eastern Serbia in the Timok Region, the cult of household hospitality is still fostered. The Timok region belongs to the underdeveloped parts of Serbia and starting from the fact that the growth of local economy capacity also leads to overall regional development, the development of rural tourism could contribute to the well-being of the region. The paper examines sustainable development directions of rural tourism, taking into account the economic,

Keywords: environmental and social components, which are elements of sustainability. The authors apply Multi-Criteriarural tourism, sustainability, Timok region, $M C D M$, ELECTRE, AHP Decision-Making methods, ELECTRE as main, and AHP as an auxiliary method in the selection of an adequate and optimal solution. The aim of the paper is choosing the

JEL: 018, Q013, Z32 optimal projects for the development of rural tourism in the Timok region, based on well-defined criteria, among the several proposed projects.
\end{abstract}

(C) 2020 EA. All rights reserved.

\section{Introduction}

Considering the views of many authors (Pearce at al., 1989; Bramwell, 1994; Seaton et al., 1994), rural tourism destinations can be defined as broader areas with natural and forested environments where particular natural, economic and socio-cultural features exist, such as tradition, local co-operation, trust, and good relationships and agriculture represents an economic branch with specificities and developments that do not comply with the classical economic laws (Drăgoi et al., 2018). These elements create a special tourism product that is primarily based on a small-scale economy, friendly to the

1 Biljana Ilić, Ph.D., Professor, Megatrend University of Belgrade, Faculty of Management, Kraljevica bb Street,19000 Zajecar, Serbia, Phone:+381 62331 077, E-mail:biljana.ilic@ fmz.edu.rs, ORCID ID (https://orcid.org/0000-0001-6137-8478)

2 Gordana Djukic, Ph.D., Researcher Associate, University of Belgrade, Faculty of Economics, Kamenička 6 Street, 11000 Belgrade, Serbia, Phone:+381 691688599 , E-mail:gordanadkc048@gmail.com, ORCID ID (https://orcid.org/0000-0001-5419-0725)

3 Mladenka Balaban, Professor, Belgrade Banking Academy, Zmaj Jovina 12, 11000 Belgrade, phone number +38169310572, e-mail mladenka.balaban@bba.edu.rs, ORCID ID (https://orcid.org/0000-0003-0170-6622)

http://ea.bg.ac.rs 
environment, "colored" by ethnic elements, in other words, it is the "sustainable" form of tourism. Bremwell \& Lane (1994) describe rural tourism as a multiple activity, not just rural tourism.

Rural tourism represents tourism in rural households, but also certain vacations and places of residence like rural areas, as well as manifestations, festivals, recreations, production and sale of handicrafts and agricultural products (Košić, 2009). Rural tourism is therefore seen as a means of addressing the problem of weakening the agricultural potentials of agricultural areas to provide additional income (OECD, 1994; Davies \& Gilbert, 1992; Alexander \& McKenna, 1998).

Serbia, especially its rural regions, is a country extremely rich in colorful flora and fauna, geothermal springs, healing mud, organic product production, and cultivation, as well as diverse folklore and cultural heritage. Therefore, it is necessary to implement a sustainable rural tourism policy in the future to maximize the positive and minimize the negative effects (Gajić, T., 2010). Rural areas in Serbia differ in economic, socio-cultural and demographic terms. The differences are conditioned by their geomorphological characteristics, population, economic structure, infrastructural equipment, as well as development potentials. Based on the fact that rural tourism in Serbia is still in development, the authors identified potentials for development and highlighted the disadvantages that hinder the rapid development of this large primary tourism in Serbia, especially the less developed regions of the country like the Timok region.

The first part of the paper deals with the study of relevant literature and description of the general characteristics of the Timok region, while the second presents the analysis and selection of one of the proposed development directions, i.e. projects that would most assist in solving the current situation regarding certain development elements of rural tourism in the Timok region. The methodology used in this paper is the application of Multi-Criteria Decision Making, namely the ELECTRE method in its basic version and the AHP method as ancillary (to calculating the criteria weights). Finally, the authors propose a concrete application and give reasons why the chosen development direction is most suitable for the development of rural tourism in Eastern Serbia, in particular, the Timok region.

\section{Timok region - general characteristics and tourism potential}

The Timok region is located in the eastern part of Serbia. It borders with Romania to the North and Bulgaria to the East. It stretches between the Danube with two corridors: Corridor X (Serbia) and Corridor IV (Bulgaria) (Štetić, S., Cvijanović, D. \& Šimičević, D. (2014). The Timok region lies in an area of $7.133 \mathrm{~km}^{2}$ and covers two districts Zajecar and Bor, i.e. the municipalities of Zajecar, Knjazevac, Boljevac, Sokobanja, Bor, Negotin, Majdanpek, and Kladovo. The area of the Timok region occupies $8,07 \%$ of the total area of entire Serbia $\left(88.361 \mathrm{~km}^{2}\right)$. The territory is populated by 284.112 inhabitants, which represents $3 \%$ of the total population of Serbia. Taking 
into account the fact that the growth of local economy capacities also leads to overall regional development, the Strategy of Regional Economic Development of the Timok region was drafted which is a basic component of the process of present and future work of RARIS's- Regional Development Agencies of East Serbia. The goal of local development is to unify the changes that are planned for the future and that creates a sustainable business environment. A sustainable business environment would provide predictability of factors relevant to business, opportunities for attracting direct investment and increasing employment, attractiveness for investing and making profit, for both existing and new market entrants, opportunities for personal and professional affirmation, incentive for domestic and foreign investments in the local community, new quality of life in the local community, with effects on the whole region but also the possibility of developing rural tourism in this part of the country (Ilić, B. \& Stojanović, D., 2019). To narrow down / refine the thematic focus of each strategic development priority, the directions of development with the highest potential have been identified. The regional development strategy of the Timok region will achieve the overall objective through the priority areas of development, strategic and cross-sectoral or horizontal priorities. The strategic development priorities include agriculture and food processing, energy based on renewable energy sources, tourism as well as the exploitation and processing of mineral resources. Horizontal priorities linking these sectors are transported in the region, support for investment and entrepreneurial spirit, the region's human resources (which are increasingly depleted) and a healthy environment (Ilić, B., 2016). Development can be achieved by sustainable consumption (Sima \& Gheorghe, 2015) and country of origin serves as a very important basis for this consumption (Šapić et al., 2018). All that that require an integrated approach to the social, economic, environmental, and technological environment (Nica et al., 2018).

The tourism potential of the Timok region is unevenly developed. From relatively developed - Sokobanja, archeological sites "Felix Romuliana" and Lepenski Vir, Stara Planina Nature Park (Babin zub), Djerdap National Park, Gamzigrad Spa, Brestovac Spa, to underdeveloped cities - Zajecar and Bor and other municipal centers, with over 50 cultural, artistic and sporting events, natural and cultural-historical sights, hunting grounds, tourist spots in the neighborhood and the beginnings of rural tourism in a small number of surrounding villages.

The existing tourists and recreational offer of the whole Timok region are not sufficiently recognized and developed (Ilić, B., 2020). Considering the facts, based on the Regional Development Strategy, five directions of development have been identified within this Strategic Development Priority. Three of them are of the first category: cultural tourism - there are a large number of cultural monuments, archaeological sites, historical monuments and natural sites in the Timok region. Sports - recreational and health (spa) tourism - there is a long tradition in this type of tourism (more than 170 years), and there is great potential in existing hydro-geothermal sources, which are used for various therapeutic purposes. Mountain tourism, due to the terrain of Stara Planina with the highest mountain peak in Serbia (Midžor, 2,169 m), which is suitable for hiking and 
skiing (it has the highest number of snow days per year in Serbia). The following priorities have been identified as priorities of the second category: Rural tourism in the region, there are still preserved authentic rural areas with traditional rural life, including unique wine cellars in Rajac, Rogljevo, and Smedovac. Specialized forms of tourism, such as hunting tourism and speleology - one of the best hunting grounds in Serbia (Dubašnica) is located on the territory of Bor Municipality, and in this area, there are three very attractive caves, which are considered the most beautiful and the longest in Serbia. The development of tourism as a strategic development priority under the Regional Development Plan could be based on two elements: 1. adaptability, to maintain long-term profitability, by continually adapting to the competitive environment and needs of tourists and enhancing the attractiveness and originality of the destination, 2. sustainability, as an ability to profitability is achieved and maintained with minimal negative impacts on society and the environment. ELECTRE and AHP Multi-Criteria Decision Making methods were used to select the optimal development direction of rural tourism in the Timok region.

\section{Multicriteria Decision Making - MCDM}

The concept of MCDM refers to situations where there are several conflicting criteria (Čupić, M., Tummala, R. \& Suknovic, M., 2001). According to many authors, MCDM is divided into multi-objective (MODM - VCO) and multi-attribute decision making (MADM - VAO) (Zimmermann, N. E., 1996). MCDM methodology based on the analysis of criteria and alternatives so that one alternative is better than the other (Durkalić et al., 2019). A typical example of this decision-making is the mathematical programming of the problem of multi-objective functions, known as the "Vectormaximum" problem (Kuhn, H.W. \& Tucker, A.W., 1951). The decision-making process consists of two components: the objectively defined projects component and the subjectively defined criteria component. The relationship between projects and criteria is established through attributes that are characterized as project characteristics, relevant to decision making and through the choice of the right solution. Decisionmakers' preferences are subjective, and examining attribute-based on criteria is a subjective process (Vanderpooten, D., 1990). Although the area of MCDM has a very diverse set of methods that differ from one another, common characteristics of problems can be separated and solved by their application (Hwang, C.L. \& Yoon, K. 1981): 1. The abundance of criteria or attributes that the decision-maker must emphasize; 2. Criterion conflict; 3. The indivisibility of individual units of measurement (a particular property or requirement); 4. Selection of the best actions from a set of predefined ones. The research in the paper is based on finding adequate development projects of a tourist resort, Timok region using the multiple criteria ELECTRE method for determining priorities between particular alternatives i.e. criteria. Therefore, this way of examining offered development projects, giving the new approach to the problem of improving tourism in the Timok region, based on the results obtained in the wider area. The ELECTRE method provides a solution to the problem of project ranking, taking into account various criteria. Some of the selected criteria could be quantified and some only 
presented qualitatively, and for the application of the ELECTRE and AHP methods, several opposing criteria that evaluated the development of Timok region projects were crucial. This means that certain criteria, such as distance (from the city), the number of geothermal wales, activity, and (negative) impact on environmental protection, were related to immeasurable units. The AHP method was used as an auxiliary method for determining the weighted values of the criteria, which certainly contributes to the objectivity of project selection. The concept of applying multi-criteria decision-making goes through several stages, which will be explained in more detail.

\section{ELECTRE and AHP methods}

The ELECTRE (Elimination and Choice Translating Reality) method was developed by Bernard Lee Roy (1968) as a response to the existing decision-making methods and as part of the Multicriteria Decision Theory. This method occupies a very significant place in the theory of Multi-Criteria Decision Making and in the papers of Vincke, Roy, Vanderpooten and other authors who researched the field of MCDM (Vincke, P., 1992., \& Roy, B., Vanderpooten, D.,1996). The ELECTRE method has several versions (ELECTRE I-IV). In practice, the most commonly encountered is the ELECTRE I method for determining the partial ordering of alternatives, as well as the ELECTRE II method for completely arranging a set of alternatives (Nikolić, M., 2009a). ELECTRE I was created between 1993 and 1996 (Roy, B., 1993). In the further evolution, ELECTRE II, ELECTRE III, ELECTRE IV, as well as two further upgrades, ELECTRE IS and ELECTRE TRI, were created (Hokkanen, J. \& Salminen, P., 1997). They differ in the way they are applied and in the type of problems they solve (Simpson, L., 1996). Simpson compared the SMART method to the ELECTRE method and concluded that "there are no major differences between these methods, however, that it is obvious that one method is stronger than the other", favoring the ELECTRE method (Simpson, L., 1996). The ELECTRE method could be viewed as a philosophy of a decision aid (Mousseau, V., Roy, B. \& Sommerlatt, I., 2000). The following section describes the main 9-step ELECTRE method and the auxiliary AHP method. The main steps of the ELECTRE method include: First, establish a decision matrix. Criteria shown as qualitative values need to be changed into quantitative values. The authors used the following criteria: 1 - very low, 3- low, 5 - average, 7 - high, and 9 - very high. A numerical scale, which is using for this purpose, is shown in Table 1:

Table 1. Transformation of linguistic scales into quantitative values

\begin{tabular}{|l|l|l|}
\hline \multirow{2}{*}{ Linguistic scale } & Quantitative value & \multicolumn{2}{|l|}{} \\
\cline { 2 - 3 } & Benefit - max & Cost - min \\
\hline Very high & 9 & 1 \\
\hline High & 7 & 3 \\
\hline Average & 5 & 5 \\
\hline Low & 3 & 7 \\
\hline Very low & 1 & 9 \\
\hline
\end{tabular}


Step 1. Calculate the normalized decision matrix. The normalized value $r_{i j}$ is calculated as (Roy, B., Présent, M., Silhol, D. 1986)

$$
r_{i j}=x_{j} / \sqrt{\sum_{k=1}^{m} x_{k}^{2}} \text {, }
$$

where ${ }^{x_{i j}}$ is the rating of alternative ${ }^{A}$ concerning the criteria $C_{j}, i=1, \ldots, m, m$ is the number of alternatives, and ${ }^{j=1, \ldots, n,} n$ is the number of criteria (Roy, B., Présent, M. \& Silhol, D. 1986, Nikolić, M., 2009c).

Step 2. Create the weighted normalized decision matrix. The weighted normalized value $v_{\ddot{j}}$ is calculated as(Roy, B., Présent, M. \& Silhol, D. 1986)

$v_{\ddot{y}}=w_{j} r_{j}$.

Step 3. Determine concordance $C_{p}$ and discordance ${ }^{p}$ sets by using followsformulae(Roy, B., Présent, M. \& Silhol, D. 1986):

$$
\begin{aligned}
& C_{p}=\left\{j \mid x_{\dot{p}} \geq x_{\dot{j}}\right\}, \\
& D_{p}=J-C_{p}=\left\{j \mid x_{\dot{p}}<x_{\dot{j}}\right\} .
\end{aligned}
$$

where $J=\{\mathrm{j} \mid \mathrm{j}=1, \ldots, \mathrm{n}\}$ (all criteria).

Step 4. Define the concordance matrix (Cpr) based on the concordance sets. The elements of this matrix are the concordance indices and they are calculated as (Roy, B., Présent, M. \& Silhol, D. 1986):

$$
c_{p}=\sum_{j \in C p r} w_{j} .
$$

Step 5. Determine the discordance matrix (Dpr)based on the discordance sets. The elements of this matrix are the discordance indices determined by the following formula (Roy, B., Présent, M. \& Silhol, D. 1986):

$$
d_{p}=\frac{\max _{j \in D p r}\left[v_{\dot{p}}-v_{\dot{j}}\right]}{\max _{j \in J}\left[v_{\dot{p}}-v_{\dot{j}}\right]}
$$

where $v_{e r} v_{r j}$ are elements of the weighted normalized decision matrix.

Step 6. Determine the matrix of concordance domination (Mcd), based on the average index of concordance - AIC by using formula (Roy, B., Présent, M. \& Silhol, D. 1986): 


$$
A I C=\sum_{p=1}^{m} \sum_{r=1}^{m} \frac{c_{p}}{m(m-1)},
$$

"Elements of concordance domination matrix are calculated on the basis of criteria: $m c d_{p r}=1$, for $c_{p r} \geq A I C ; m_{p r}=0$, for $c_{p r}<A I C$ "' (Roy, B., Présent, M. \& Silhol, D. 1986).

Step 7. Analogously to the matrix of concordance domination, there is a need for determination of the matrix of discordance domination (Ddm) based on the average index of discordance - AID, as follows (Roy, B., \& Vanderpooten, D., 1996):

$$
A I D=\sum_{p=1}^{m} \sum_{r=1}^{m} \frac{d_{p}}{m(m-1)},
$$

Matrix of discordance domination is calculated on criteria: $m d d_{p r}=1$, for $d_{p r} \leq A I D$; $m d d_{p r}=0$, for $d_{p r}>A I D$.

Step 8. Determine the matrix of aggregate domination whose elements are equal to the product of the elements on a certain position in matrices of concordance (Mcd) and Matrix of discordance (Mdd) domination (Roy, B., \& Vanderpooten, D., 1996):

$$
\operatorname{mad}_{p}=m c d_{p} \cdot m d d_{p} \text {. }
$$

Step 9. Less desirable actions are eliminated, while one or more alternatives are separated as most desirable (Roy, B., \& Vanderpooten, D., 1996). Therefore, the ELECTRE I method provides a partial order of actions (Adamovic, Z, Nadrljanski, Dj. \& Tomasevic, M.,2008).

AHP method (Analytical Hierarchy Process) was proposed by Saaty, T. L. (1977,1980) to model subjective decision-making processes based on multiple criteria in a hierarchical system. This method is very convenient for determining the relative criteria weights (Saaty, T. L. (1990). Three of the most used methods for determining the weights in AHP are the average of normalized columns (ANC), normalization of row average (NRA), and normalization of the geometric mean of the rows(Huang Y.S., Liao J.T. \& Lin, Z.L., 2009), (Čupić, M., Tummala, R. \&Suknovic, M., 2001). The AHP method includes the following steps:

Step 1. Construct a pairwise comparison matrix using the fundamental scale of the AHP (Table 2).

Table 2. Fundamental scale of AHP

\begin{tabular}{|l|l|}
\hline The evaluation scale & Definition \\
\hline 1 & Equal imported \\
\hline 3 & Slightly more importance \\
\hline 5 & Strongly more importance \\
\hline 7 & Demonstrably more importance \\
\hline 9 & Absolutely more importance \\
\hline $2,4,6,8$ & The medium value of the adjacent scale \\
\hline
\end{tabular}

Source: Saaty, T.L. (1980). 
Table 3. Pairwise comparison matrix

\begin{tabular}{l||lllll}
\hline & $C_{1}$ & $C_{2}$ & $C_{3}$ & $\ldots$ & $C_{n}$ \\
\hline \hline$C_{1}$ & $a_{11}$ & $a_{12}$ & $a_{13}$ & $\cdots$ & $a_{1 n}$ \\
\cline { 2 - 6 }$C_{2}$ & $a_{21}$ & $a_{22}$ & $a_{23}$ & $\ldots$ & $a_{2 n}$ \\
\cline { 2 - 6 } & & & - & $\cdots$ & $\cdot$ \\
\hline$C_{n}$ & $a_{n 1}$ & $a_{n 2}$ & $a_{n 3}$ & $\cdots$ & $a_{n n}$ \\
\hline
\end{tabular}

Source: Saaty, T.L. (1980).

In the pairwise comparison matrix (Table 3 ) where ${ }^{a_{i j}}$ denotes the comparative importance of criterion $C_{i}$ concerning to criterion ${ }^{C_{j}}$. In the matrix $a_{i j}=1$, when $i=j$ and $a_{j i}=a_{j}$, while $n$ denotes the number of criteria (Saaty, T. L., 1994).

Step 2. Calculate the relative normalized weight $w_{j}$ of each criterion by using the following formulae (Saaty, T. L., 1994):

$$
\begin{aligned}
& G M_{i}=\sqrt[N]{\prod_{i=1}^{N} a_{i j}} \\
& W_{j}=\frac{G M_{i}}{\sum_{i=1}^{N} G M_{i}}
\end{aligned}
$$

where $G M$ is a geometric mean.

Step 3. Determine the maximum eigenvalue $\lambda_{\max }$ of the comparison matrix and calculate the consistency index $\boldsymbol{C}$ (Saaty, T. L. (1994):

$$
\mathbb{C}=\left(\lambda_{\max }-n\right) /(n-1) \text {, for } \mathrm{n}>1 \text {. }
$$

Step 4. Obtain the random index $R$ for the number of criteria used in decision making (Table 4). Table 3 shows the values of the random consistency index for different matrix sizes.

Table 4. Random consistency index for different matrix sizes

\begin{tabular}{|l|l|l|l|l|l|l|l|l|l|}
\hline $\begin{array}{l}\text { Ma trix } \\
\text { size (n) }\end{array}$ & 1 & 2 & 3 & 4 & 5 & 6 & 7 & 8 & 9 \\
\hline RI & 0.00 & 0.00 & 0.58 & 0.90 & 1.12 & 1.24 & 1.32 & 1.41 & 1.45 \\
\hline
\end{tabular}

Source: (Saaty, T.L., 2014)

Step 5. For $\mathrm{n}>2$ calculate the consistency ratio $\boldsymbol{R}$ by using the following formula (Saaty, T.L., 1980). 


$$
C R=C I / R I
$$

where RI is the random consistency index, and its value is determined based on the matrix size(Saaty, T.L., 1980).

and

$$
m s d_{p}=0, \text { for }_{p}<P I S .
$$

\section{Applying ELECTRE and AHP methods for ranking the sustainable directions projects of the Timok region}

For the optimal selection of rural tourism development directions of the Timok region, a group of experts in the RARIS development agency is made up of financial consultants, accountants, as well as prominent managers of companies that do well in this area, suggested rural tourism development directions. Directions that were taken into account were financially acceptable and environmentally had little impact on the natural environment. Based on the geographical location and tourism development potential of the Timok region, five development directions have been identified, ie. the following five tourism projects are in the field of rural tourism:

- Mountain tourism,

- Hunting and fishing tourism,

- Eco-tourism,

- Health - sports and recreational tourism,

- Cultural tourism.

Each project, i.e. alternative of the future development of the region, is defined by certain attributes, ie. by the criteria. After talking to a team of experts from the RARIS for development of the Timok region, the following criteria for projects evaluation (with attributes in brackets) were defined:

1. FIN -Investing in existing or new capacities (values in Euros),

2. P- Profit -a benefit to the rural community as income (tourism revenue expressed in Euros),

3. D - Distance - distance from the city distance - (average in kilometers from the cities of Bor, Zajecar, Negotin and Kladovo, this distance should be shorter),

4. GW - Geothermal Wales - concentration of sources of geothermal energy and clean water (determined to be as high as possible),

5. A - Activity - the opportunity to participate in the activities, traditions, and way of life of the local population, (it has been found necessary that the involvement should be greater),

6. ENP - Environmental protection - Impact on the conservation of the environment, 
history, and location (it has been determined that maximum environmental management is required).

The criteria are set on unique measures of defined attributes, measures for each development direction. Investing in existing or new capacities (FIN) and profit for the rural community as income are expressed in the form of cash investments with additional parameters (taxes, donations, discounts, fees). The remaining four criteria, based on the team of experts, gained importance in relation to other's ratings from one to ten. The process of summarizing attributes into criteria involves the first level of subjectivity. At this level, the criteria must be accepted by decision-makers. The second level processes preference data, reflecting the relative importance of each criterion. At this level, decision-makers have the opportunity to express their views on their value systems. The initial matrix is composed of the selected development directions and their inputs, based on the given criteria and given in Table 5.

Table 5. Performance matrix for five projects and five criteria

\begin{tabular}{|c|c|c|c|c|c|c|}
\hline Criteria & FIN & $\mathbf{P}$ & D & GW & $\mathbf{A}$ & ENP \\
\hline Projects & $\min$ & $\max$ & $\min$ & $\max$ & $\max$ & $\max$ \\
\hline $\begin{array}{l}\text { (Mountain tourism } \\
\text { PRO }_{1} \text { ) }\end{array}$ & 500,000 & 900,000 & very high & medium & medium & medium \\
\hline $\begin{array}{l}\text { Hunting and fishing } \\
\text { tourism }\left(\mathrm{PRO}_{2}\right)\end{array}$ & 450,000 & 300,000 & high & low & very high & high \\
\hline $\begin{array}{l}\begin{array}{l}\text { Eco-tourism } \\
\left(\mathrm{PRO}_{3}\right)\end{array} \\
\end{array}$ & 170,000 & 700,000 & high & medium & high & medium \\
\hline $\begin{array}{l}\text { Health and sport } \\
\text { recreation }\left(\mathrm{PRO}_{4}\right)\end{array}$ & 650,000 & 950,000 & very high & high & low & medium \\
\hline $\begin{array}{l}\text { Cultural tourism } \\
\left(\mathrm{PRO}_{5}\right)\end{array}$ & 120,000 & 350,000 & high & low & very high & medium \\
\hline
\end{tabular}

Source: Author's research

The proposed projects were evaluated based on the given criteria, while their evaluation was carried out with maximum objectivity and with the opinion of experts. Based on Table 5, an initial decision matrix, shown in Table 6, was formed.

Table 6. Initial decision matrix

\begin{tabular}{|l|c|c|c|c|c|c|}
\hline Criteria & FIN & P & D & GW & A & ENP \\
\hline Projects & $\min$ & $\max$ & $\min$ & $\max$ & $\max$ & $\max$ \\
\hline PRO $_{1}$ & 500,000 & 900,000 & 9 & 5 & 5 & 5 \\
\hline PRO $_{2}$ & 450,000 & 300,000 & 7 & 3 & 9 & 7 \\
\hline PRO $_{3}$ & 170,000 & 700,000 & 7 & 5 & 7 & 5 \\
\hline PRO $_{4}$ & 650,000 & 950,000 & 9 & 7 & 3 & 5 \\
\hline PRO $_{5}$ & 120,000 & 350,000 & 7 & 3 & 9 & 5 \\
\hline
\end{tabular}

Source: Author's research

Using formula 1, based on the values in Tables 5 and 6 , the normalized decision matrix was calculated (Table 7). This is the first step of the ELECTRE. 
Table 7. Normalized decision matrix

\begin{tabular}{|l|c|c|c|c|c|c|}
\hline & FIN & P & D & GW & A & ENP \\
\hline PRO1 & 0.521 & 0.579 & 0.511 & 0.462 & 0.319 & 0.409 \\
\hline PRO2 & 0.469 & 0.193 & 0.398 & 0.277 & 0.574 & 0.573 \\
\hline PRO3 & 0.177 & 0.450 & 0.398 & 0.462 & 0.447 & 0.409 \\
\hline PRO4 & 0.678 & 0.611 & 0.511 & 0.647 & 0.191 & 0.409 \\
\hline PRO5 & 0.125 & 0.225 & 0.398 & 0.277 & 0.574 & 0.409 \\
\hline
\end{tabular}

Source: Author's research

Based on the opinion of two research associates and on the opinion of the one trainee researcher (fields: Economy, Sociology, and Ecology), the weight of criteria was determined by applying the AHP method. The criteria were compared in pairs, and the final values were obtained using the arithmetic mean. The final results of the weighting criteria are as follows (Tables 8, 9, 10 and 11).

Table 8. Criterion Weights - Associate Researcher $1(\mathrm{CR})=7.76 \%$

\begin{tabular}{|l|l|l|l|l|l|l|l|l|}
\hline & FIN & P & D & GW & A & ENP & Cr & Wt \\
\hline FIN & 0,05 & 0,33 & 0,14 & 0,20 & 0,33 & 1,00 & FIN & 0.044 \\
\hline P & 3,000 & 1,00 & 3,00 & 1,00 & 5,00 & 7,00 & P & 0.330 \\
\hline D & 7,000 & 0.333 & 1,00 & 1,00 & 5,00 & 5,00 & D & 0.251 \\
\hline GW & 5,000 & 1,000 & 1,000 & 1,00 & 3,00 & 3,00 & GW & 0.231 \\
\hline A & 3,000 & 0.200 & 0.200 & 0,333 & 1,00 & 3,00 & A & 0.094 \\
\hline ENP & 1,000 & 0,143 & 0,200 & 0,333 & 0,333 & 1,00 & ENP & 0,049 \\
\hline
\end{tabular}

CR - Consistency Ratio

Source: Author's research

Table 9. Criterion Weights - Associate Researcher 2 (CR) $=8,58 \%$

\begin{tabular}{|l|l|l|l|l|l|l|l|l|}
\hline & \multicolumn{1}{|c|}{ FIN } & \multicolumn{1}{|c|}{$\mathbf{P}$} & \multicolumn{1}{|c|}{$\mathbf{D}$} & \multicolumn{1}{|c|}{$\mathbf{G W}$} & \multicolumn{1}{|c|}{$\mathbf{A}$} & \multicolumn{1}{|c|}{ ENP } & \multicolumn{1}{c|}{ Cr } & \multicolumn{1}{|c|}{ Wt } \\
\hline FIN & 0,05 & 0,33 & 0,33 & 0,14 & 0,33 & 1,00 & FIN & 0.052 \\
\hline $\mathbf{P}$ & 3,000 & 1,00 & 1,00 & 3,00 & 3,00 & 9,00 & $\mathrm{P}$ & 0.311 \\
\hline $\mathbf{D}$ & 3,030 & 1,000 & 1,00 & 5,00 & 3,00 & 3,00 & $\mathrm{D}$ & 0.312 \\
\hline GW & 7,143 & 0.333 & 0.200 & 1,00 & 1,00 & 5,00 & GW & 0.156 \\
\hline $\mathbf{A}$ & 3,030 & 0.333 & 0.333 & 1,000 & 1,00 & 3,00 & $\mathrm{~A}$ & 0.123 \\
\hline ENP & 1,000 & 0,111 & 0,200 & 0,333 & 0,333 & 1,00 & ENP & 0,046 \\
\hline
\end{tabular}

Source: Author's research 
Table 10. Criterion Weights - Trainee Researcher $3(\mathrm{CR})=9,84 \%$

\begin{tabular}{|l|l|l|l|l|l|l|l|l|}
\hline & \multicolumn{1}{|c|}{ FIN } & \multicolumn{1}{|c|}{$\mathbf{P}$} & \multicolumn{1}{c|}{$\mathbf{D}$} & \multicolumn{1}{|c|}{ GW } & \multicolumn{1}{c|}{$\mathbf{A}$} & \multicolumn{1}{|c|}{ ENP } & \multicolumn{1}{c|}{ Cr } & \multicolumn{1}{c|}{ Wt } \\
\hline FIN & 0,05 & 0,14 & 0,14 & 0,14 & 0,33 & 0,33 & FIN & 0,027 \\
\hline $\mathbf{P}$ & 7,143 & 1,00 & 7,00 & 5,00 & 7,00 & 9,00 & P & 0.541 \\
\hline D & 7,143 & 0.143 & 1,00 & 1,00 & 0,33 & 1,00 & D & 0.105 \\
\hline GW & 7,143 & 0.200 & 1,000 & 1,00 & 1,00 & 1,00 & GW & 0.121 \\
\hline A & 3,030 & 0.143 & 3,030 & 1,000 & 1,00 & 1,00 & A & 0.117 \\
\hline ENP & 3,030 & 0,111 & 1,000 & 1,000 & 1,000 & 1,00 & ENP & 0,088 \\
\hline
\end{tabular}

Source: Author's research

Table 11. The arithmetic mean of the criteria weights

\begin{tabular}{|l|l|}
\hline \multicolumn{1}{|c|}{ Criterion } & \multicolumn{1}{c|}{ Weight } \\
\hline FIN & 0.042 \\
\hline P & 0.395 \\
\hline D & 0.222 \\
\hline GW & 0.169 \\
\hline A & 0.111 \\
\hline ENP & 0,061 \\
\hline$\Sigma$ & 1 \\
\hline
\end{tabular}

Source: Author's research

Step 2 is creating the weighted normalized decision matrix using formula 2 . The values of the elements of the weighted normalized matrix are given in Table 12.

Table12.The Weighted normalized matrix

\begin{tabular}{|l|c|c|c|c|c|c|}
\hline & FIN & $\mathbf{P}$ & $\mathbf{D}$ & $\mathbf{G W}$ & $\mathbf{A}$ & ENP \\
\hline $\mathbf{P}_{\mathbf{1}}$ & 0.021 & 0.228 & 0.113 & 0.078 & 0.035 & 0.024 \\
\hline $\mathbf{P}_{\mathbf{2}}$ & 0.019 & 0.076 & 0.088 & 0.046 & 0.063 & 0.034 \\
\hline $\mathbf{P}_{\mathbf{3}}$ & 0.007 & 0.177 & 0.088 & 0.078 & 0.049 & 0.024 \\
\hline $\mathbf{P}_{\mathbf{4}}$ & 0.028 & 0.241 & 0.113 & 0.109 & 0.021 & 0.024 \\
\hline $\mathbf{P}_{\mathbf{5}}$ & 0.005 & 0.088 & 0.088 & 0.046 & 0.063 & 0.024 \\
\hline Cr Weights & 0.042 & 0.395 & 0.222 & 0.169 & 0.111 & 0,061 \\
\hline
\end{tabular}

Source: Author's research

ELECTRE is determining concordance and discordance sets by using formulae 3 and 4 (Roy, B., Présent, M. \& Silhol, D. 1986). The next fourth step is defining the concordance matrix (Cpr) based on the concordance sets. The elements of this matrix are calculated by formula 5 and presented in Table 13. Determining the discordance matrix (Dpr) based on the discordance sets is step five of the ELECTRE method, while the elements of this matrix are determined by formula 6 and there are shown in 
Table 14. Step six is determining the matrix of concordance domination (Mcd, Table 15), based on the average index of concordance (using formula 7). Determination of the matrix of discordance domination (Ddm) based on the average index of discordance is step seven of the ELECTRE (using formula 8) and these elements are shown in Table 16.

Table 13.The concordance matrix - $\mathrm{Cpr}$

\begin{tabular}{|l|l|l|l|l|}
\hline 0 & 0.564 & 0.625 & 0.436 & 0.625 \\
\hline 0.436 & 0 & 0.394 & 0.436 & 0.563 \\
\hline 0.605 & 0.828 & 0 & 0.436 & 0.847 \\
\hline 0.847 & 0.564 & 0.625 & 0 & 0.625 \\
\hline 0.436 & 0.939 & 0.436 & 0.436 & 0 \\
\hline
\end{tabular}

Source:Author's research

Table 14. The discordance matrix - Dpr

\begin{tabular}{|l|l|l|l|l|}
\hline 0 & 0.185 & 0.496 & 1 & 0.202 \\
\hline 1 & 0 & 1 & 1 & 1 \\
\hline 1 & 0.139 & 0 & 1 & 0.159 \\
\hline 0.454 & 0.257 & 0.446 & 0 & 0.279 \\
\hline 1 & 0.690 & 1 & 1 & 0 \\
\hline
\end{tabular}

Source:Author's research

Table 15. The Matrix of concordance dominance - Mcd

\begin{tabular}{|l|l|l|l|l|}
\hline 0 & 0 & 1 & 0 & 1 \\
\hline 0 & 0 & 0 & 0 & 0 \\
\hline 1 & 1 & 0 & 0 & 1 \\
\hline 1 & 0 & 1 & 0 & 1 \\
\hline 0 & 1 & 1 & 0 & 0 \\
\hline
\end{tabular}

Source: Author's research

Table 16.The Discordance Dominance Matrix -Ddm

\begin{tabular}{|l|l|l|l|l|}
\hline 0 & 1 & 1 & 0 & 1 \\
\hline 0 & 0 & 0 & 0 & 0 \\
\hline 0 & 1 & 0 & 0 & 1 \\
\hline 0 & 1 & 1 & 0 & 1 \\
\hline 1 & 0 & 0 & 0 & 0 \\
\hline
\end{tabular}

Source: Author's research

The next step eight involves determining the matrix of aggregate dominance - MAD. In this example, the aggregate dominance matrix has the values shown in Table 17 obtained by applying formula 9 . 
Table17.The aggregate dominance matrix - MAD

\begin{tabular}{|c|c|c|c|c|}
\hline $\mathrm{P}_{1}$ & 0 & 1 & 0 & 1 \\
\hline 0 & $\mathrm{P}_{2}$ & 0 & 0 & 0 \\
\hline 0 & 1 & $\mathrm{P}_{3}$ & 0 & 1 \\
\hline 1 & 0 & 1 & $\mathrm{P}_{4}$ & 1 \\
\hline 1 & 0 & 0 & 0 & $\mathrm{P}_{5}$ \\
\hline
\end{tabular}

Source: Author's research

In the last, the ninth step of the ELECTRE method, less desirable actions, alternatives projects, i.e. development directions are eliminated $(, \rightarrow "=$,dominates over").

Table 18. shows the ranks of development directions (projects) and as can be seen, the projects that are not dominated are P2 and P5. Alternative i.e. project P1 dominates under the projects $\mathrm{P} 3$ and P5, while the project P4 also has an advantage over the projects P2 and P5.

Table 18. Final project rankings

\begin{tabular}{|l|l|}
\hline $\mathbf{P}_{4} \rightarrow \mathbf{P}_{\mathbf{1}} \mathbf{P}_{2}, \mathbf{P}_{3} \mathbf{P}_{5}$ & Domination over $\mathbf{P}_{\mathbf{1}}, \mathbf{P}_{3}, \mathbf{P}_{\mathbf{5}}$ \\
\hline $\mathrm{P}_{1} \rightarrow \mathrm{P}_{3}, \mathrm{P}_{5}$ & Domination over $\mathrm{P}_{3}, \mathrm{P}_{5}$ \\
\hline $\mathrm{P}_{2}$ & Without domination \\
\hline $\mathrm{P}_{3} \rightarrow \mathbf{P}_{2} \mathbf{P}_{5}$ & Domination over $\mathbf{P}_{2} \mathbf{P}_{5}$ \\
\hline $\mathrm{P}_{5}$ & Without domination \\
\hline
\end{tabular}

Source: Author's research

The best project is P4 -a project of Health - Sports and Recreational tourism. The research in this paper is a logical continuation of the authors' research and the breakdown of rural tourism projects into subcategories in terms of the concrete best development direction for the Timok region.

\section{Discussion}

The aim of the research focuses on the development of the Timok region of Eastern Serbia by choosing the best development direction of rural tourism. To choose the best alternative, it was necessary to objectively apply a method that would rank the alternatives and help in the decision of future investors and certain organizations (such as RARIS) in choosing the optimal solution. A team of experts from RARIS took into account and proposed rural tourism projects using the Brainstorming method. Out of all 14 proposals, a team of experts considered five that could be optimal. In its basic version, the ELECTRE method was applied to reduce costs, in other words saving time and to partially compare the proposed projects. After selecting development projects i.e. directions, the expert team of RARIS composed of research associates and trainee researchers in the fields of economics, ecology, and sociology proposed and evaluated 
the weights of the criteria, comparing the criteria in pairs. According to the ELECTRE method, one out of the five proposed was one that satisfied the choice of the optimal and best solution. The rural tourism project selected by the ELECTRE method is a health and sports and recreational tourism project. This alternative is also very logical given the fact that the Timok region abounds with hydro-geothermal energy sources that are underutilized or very little utilized.

\section{Conclusion}

The Strategy of the Timok region in Eastern Serbia should be based on Healthy- sports and recreational tourism because the investments in this project are lower than the investment of other projects of tourism. Therefore, the authors came up with the results that the project P4 is economically better than others. Taking into account the opinion of experts, together with the ranking method, the results indicate the optimum best option for multi-criteria decision-making (MCDM) and the future directions of tourism development. In the experts' opinions and on its rank in the selected methods, besides the least investment, the project of tourism requires the shortest time for realization. So, it can be said that the project of the paper presents ranking projects of the Timok region in Eastern Serbia, applying two methods of MCDM, ELECTRE I and AHP. The results demonstrate, based on these methods and after the project has been calculated that the projects of Healthy- sports and recreational tourism dominate, ie. the best project in P4. If we take into account the financial criterion, the recommendation development tourism is the most important for sustainable development of the Timok region that includes the needs of people, but also to preserve nature in the region of Eastern Serbia. This research is based on the rich nature of the Timok Region, the needs of the citizens and authors are trying to make the support of the local leaders of the region but also to be supported by the state.

\section{Conflict of interests}

The authors declare no conflict of interest.

\section{References}

1. Adamović, Z., Nadrljanski, Dj. \& Tomasevic, M. (2008). Methodology of scientific research and statistical methods in research. Monograph. University of Novi Sad, Faculty of Education, Sombor [in Serbian:Adamović, Ž., Nadrljanski, Đ. \& Tomašević, M. (2008). Metodologija naučno-istraživačkog rada i statističke metode u istraživanju. Monografija. Univerzitet u Novom Sadu, Pedagoški fakulet, Sombor, 15].

2. Alexander, N. \& McKenna, A. (1998). Rural tourism in the heart of England. International Journal of Contemporary Hospitality Management, 10 (5), 203-207.

3. Bramwell, B., \& Lane, B. (eds). (1994). Special issue on rural tourism and sustainable rural development. Journal of Sustainable Tourism, 2(1/2)), Long, P.E. [in Seaton et al., eds. Tourism the state of the art, John Wiley, Chichester]. 
4. Čupic, M., Tummala, R., \& Suknovic, M. (2001). Decision Making: Formal Approach. Faculty of Organizational Sciences, Belgrade,16 [in Serbian: Čupić, M., Tummala, R. \& Suknovic, M. (2001). Odlučivanje: formal pristup. Fakultet organization nauka, Beograd, 16].

5. Čupić, M., Tummala, R. \& Suknovic, M. (2001), Decision Making: Formal Approach. SZR Zuhra, Belgrade, 14 [in Serbian: Čupić, M. Tummala, R. \& Suknovic, M. (2001). Odlučivanje: formalni pristup. SZR Zuhra, Beograd, 14].

6. Davies, E. T. \& Gilbert, D. C. (1992). A case study of the development of farm tourism in Wales. Tourism Management, 13(1), 56-63.

7. Drăgoi, M. C., Andrei, J. V., Mieilă, M., Panait, M., Dobrotă, C. E., \& Lădaru, R. G. (2018). Food safety and security in Romania-an econometric analysis in the context of national agricultural paradigm transformation. Amfiteatru Economic, 20(47), 134-150.

8. Durkalić, D., Furtula, S., \& Borisavljević, K. (2019). Ranking tourism market performance in EMU countries: Results of PROMETHEE-GAIA approach. Menadžment u hotelijerstvu i turizmu [Hotel and Tourism Management], 7(2), 67-76.

9. Gajić, T. (2010). Tourism in the Intensification of the Economic Development of Receptive and Emitting Areas - An Example of the South Backa District. Industry, 38 (3), Belgrade, 139-155[in Serbian:Gajić, T. (2010). Turizam u funkciji intenzifikacije privrednog razvoja receptivnih i emitivnih područja - primer Južnobačkog okruga. Industrija, 38(3), Beograd, 139-155].

10. Hokkanen, J. \& Salminen, P.(1997). ELECTRE III and IV decision aids in an environmental problem. Journal of Multi-criteria Decision Analysis, 6 (4), 115 226.

11. Huang Y.S., Liao J.T. \& Lin, Z.L. (2009). A study on aggregation on group decisions. Systems Research and Behavioral Science, 26 (4), 445-454.

12. Hwang, C.L.\& Yoon, K. (1981). MultipleAttribute Decision Making: Methods and Applications. Springer-Verlag, Berlin, Heidelberg, New York, 16.

13. Ilić, B. (2016). Strategic directions of regional economic and ecological development of the tourism potential of Gamzigrad Spa. Doctoral dissertation. Megatrend University Belgrade, Faculty of Management, Zajecar [in Serbian: Strategijski pravci regionalnog ekonomskog i ekološkog razvoja turističkog potencijala Gamzigradske banje. Doktorska disertacija. Megatrend univerzitet Beograd, Fakultet za menadžment, Zaječar].

14. Ilić, B. \& Dragica Stojanović, D. (2019). Modern technologies as determinants of management of life and environment quality. Proceedings of the 10th International Conference on Freedom and Security in Real and CyberSpace, Higher Educational Institution for Applied Studies of Entrepreneurship, Belgrade, 305-320 [in Serbian: Tematski zbornik radova sa 10. Međunarodne konferencije Sloboda i bzbednost u realnom $i$ sajber prostoru, Visoka obazovna ustanova za primenjene studije preduzetništva, Beograd], 305-320. 
15. Ilić, B. (2020). Social Component of Sustainable Development and Quality of Life: Region of the Balkans, Eastern Serbia. In: Akküçük, U. (2020). Handbook of Research on Creating Sustainable Value in the Global Economy, Chapter 26, IgI Global, Boğaziçi University, 452-462,doi: 10.4018/978-1-7998-1196-1.ch026

16. Košić, K. (2009). Vojvodina Rural Tourism and Sustainable Development, Ph.D. Thesis. The University of Novi Sad, Faculty of Science, Department of Geography, Tourism and Hotel Management, Novi Sad [in Serbian: Košić, K. (2009). Ruralni turizam Vojvodine i održivi razvoj. Doktorska disertacija. Univerzitet u Novom Sadu, Prirodno-matematički fakultet, departman za geografiju, turizam i hotelijerstvo, Novi Sad].

17. Kuhn, H.W. \& Tucker, A.W. (1951). Nonlinear programming Proceedings of 2nd Berkeley Symposium. University of California Berkley, 2-20.

18. Nikolić, M., (2009). Decision-Making Methods, University of Novi Sad, Faculty of Engineering Mihajlo Pupin, Zrenjanin, 8 [in Serbian: Nikolić, M.(2009). Metode odlučivanja, Univerzitet u Novom Sadu, Tehnički fakultet Mihajlo Pupin, Zrenjanin, 8].

19. Nikolić, M., (2009a). Decision-Making Methods, University of Novi Sad, Faculty of Engineering Mihajlo Pupin, Zrenjanin, (op.cit. 76), 132 [in Serbian:Nikolić, M.(2009). Metode odlučivanja, Univerzitet u Novom Sadu, Tehnički fakultet Mihajlo Pupin, Zrenjanin, (op.cit. 76), 132].

20. Nikolić, M. (2009b). Decision-Making Methods, University of Novi Sad, Faculty of Engineering Mihajlo Pupin, Zrenjanin, (op.cit. 76), 132 [in Serbian:Nikolić, M.(2009). Metode odlučivanja, Univerzitet u Novom Sadu, Tehnički fakultet Mihajlo Pupin, Zrenjanin, (op.cit. 78), 132].

21. Nikolić, M. (2009c). Decision-Making Methods, University of Novi Sad, Faculty of Engineering Mihajlo Pupin, Zrenjanin, (op.cit. 76), 138 [in Serbian:Nikolić, M.(2009). Metode odlučivanja, Univerzitet u Novom Sadu, Tehnički fakultet Mihajlo Pupin, Zrenjanin, (op.cit. 78), 138].

22. Nica, E., Sima, V., Gheorghe, I., \& Drugau-Constantin, A. (2018). Analysis of Regional Disparities in Romania from an Entrepreneurial Perspective. Sustainability, 10(10), 3450.

23. Mousseau, V., Roy, B., \& Sommerlatt, I. (2000). Elaboration d'un outil d'aide `a la decision en vue de l'evolution de la tarification des transports publics en Ile de France, Journal of Decision Systems, 9 (2),289-315.

24. OECD (1994). Tourism strategies and rural development. Organization for economic co-operation and development, Paris.

25. Pearce D.W., Markandya, A. \& Barbier, E.B. (1989). Blueprint for a green economy. Earthscan publication, London, 1.

26. Roy, B., Présent, M. \& Silhol, D. (1986). A programming method for determining which Paris Metro stations should be renovated. European Journal of Operational Research, 24(2), 193-334. 
27. Roy, B. (1993). Decision science or decision-aid science? European Journal of Operational Research, 66, 184-203.

28. Roy, B., \& Vanderpooten, D. (1996). The European School of MCDA, Emergence, Basic Features, and Current Works, Journal of Multi-Criteria Decision Analysis 5, (1), 22-37.

29. Saaty, T.L. (1980). The Analytical Hierarchy Process: Planning, Priority Setting, Resource Allocation. McGraw-Hill, New York, 1980.

30. Saaty, T. L. (1990). How to make a decision: the analytic hierarchy process. European Journal of Operational Research, 48(1)).

31. Saaty, T. L. (1994). Fundamentals of Decision Making and Priority Theory with AHP. RWS Publications, Pittsburgh.

32. Saaty, T.L., (2014). The Analytical Hierarchy Process: Planning, Priority Setting, Resource Allocation. McGraw-Hill, New York, 1980.

33. Schwenk, C. \& Thomas, H. (1983). Formulating the mess: The role of decision aids in the problem formulation. OMEGA 11(3), 239-252.

34. Simpson, L. (1996). Do decision-makers know what they prefer? MAVT and ELECTRE II. Journal of the Operational Research Society, 47, 919-929 (Op. cit., 78).

35. Sima, V., \& Gheorghe, I. G. (2015). Changing Consumption Patterns in Green Economy. In Agricultural Management Strategies in a Changing Economy (pp. 186-212). IGI Global.

36. Stanujkić D., Magdalinović N., Milanović D., Magdalinović S. \& Popović G. (2014). An Efficient and Simple Multiple Criteria Model for a Grinding Circuit Selection Based on MOORA Method. Informatica, 2 (1). Vilnius University, 73-93.

37. Štetić, S., Cvijanović, D. \& Šimićević, D. (2014). Special forms of tourism in the Danube region of Serbia. Monograph. Institute for Agricultural Economics, Belgrade [in Serbian:Štetić, S., Cvijanović, D. \& Šimičević, D. (2014). Posebni oblici turizma Dunavskog regiona Srbije. Monografija. Institut za ekonomiku poljoprivrede, Beograd ].

38. Šapić, S., Furtula, S., \& Durkalić, D. (2018). Prestige and national identity as predictors of food products purchase. Economics of Agriculture, 65(2), 643-657.

39. Vanderpooten, D. (1990). The construction of prescriptions in outranking methods. [in C.A. Bana e Costa (ed.), Readings in Multiple Criteria Decision Aid, SpringlerVerlag, Berlin], 184-215.

40. Vincke, P. (1992). Multicriteria Decision - Aid, John Waley, and Sons, Chichester.

41. Zimmermann, N.E. (1996). Ein klimasensitives, räumliches Vegetationsmodell für die alpine Stufe der Schweiz. Ph.D. Thesis. Universität Bern. 